\title{
THE TYPE OF CHYTRIDIUM OLLA A. BRAUN
}

\author{
F.K. Sparrow*
}

Among freshwater zoosporic Phycomycetes, the simple, so-called "chytrids" with posteriorly uniflagellate zoospores have led all others in numbers and diversity of species revealed by investigations of the past three decades. It becomes important, therefore to typify as clearly as possible the Chytridiales and allied orders of these fungi (Blastocladiales, Monoblepharidales, Harpochytriales) which compose the Chytridiomycetes (Sparrow, 1958). This is particularly true of the Chytridiales and the genus Chytridium itself, since these are basic, as it were, to the others.

Taxa of chytridiaceous fungi were established starting with the third decade of the 19th century. Physoderma, an obligate parasite of vascular plants, for example, was described by Wallroth in 1833, although, in fact, its true affinities were not proven until publication of de Bary's great text of 1884 when he reported Goebel and he had found chytrid zoospores produced by resting spores in two species of the genus. Alexander Braun, de Bary's teacher, in a series of papers $(1851,1855,1856)$ pointed out clearly the parasitic nature of these fungi and in his 1856 paper devoted considerable attention to their systematics. In establishing the genus Chytridium for these 1 -celled forms, all parasites of algae and fungi and some of which have been subsequently placed elsewhere, he clearly indicated that Chytridium olla on Oedogonium was what we would now regard as the "type". Hence, Chytridium olla, becomes of prime importance and a look at the original material highly desirable.

Recently, in the course of a successful search for types in the general and Wallroth's herbarium at the Institute de Botanique at Strasbourg at which de Bary was once Professor, I was fortunate to find a small bit of dried algae in a packet he labelled "Chytridium olla A. Br. Oedogonium Landsboroughii, Freiburg in B. legit. A. Braun". A bit of this soaked in lacto-phenol, upon examination yielded many oogonia of the alga carrying plants of the parasitic Chytridium. A comparison of Figures 2-4 with Figure 1 clearly reveals the unique features of Braun's fungus: The jug-like sporangium with conspicuous operculum (Fig. 2, 3) with broad unbranched haustorial-like subsporangial rhizoidal tube entering the algal egg (Fig. 4). This tube I am convinced gives rise to a series of branched rhizoids inside the ooplasm as can be seen in Fig. 4. I was able to hydrolyze the food granules (starch) and bring parts of the branched rhizoidal system into view. Figure 3 shows not only the broad tube and clearly operculate sporangium, but most remarkably, the cleaved out zoospores within. A second adjacent sporangium just out of focus has like contents. A few endobiotic resting spores were found (Fig. 5).

Too much significance should probably not be put on the sizes of parts because of the century or more of dryness and subsequent treatment with lactophenol. Nonetheless, it is of interest to compare Braun's measurements with those from the treated herbarium material as is done below.

* Botany Dept., University of Michigan, Ann Arbor, Mich., U.S.A. Assisted by NSF Grant GB-3333. I am indebted to Professor H. G. Maresquelle for permission to study the material available in the Strasbourg Herbarium, and for the assistance of Mr. Kapp. 
Braun, I 856

Sporangium

Operculum diameter

Zoospore

Rhizoid diameter

Resting spore

$$
50-66 \times 25-37,11 \mathrm{~m}
$$$$
\mathrm{I} 2.51 \mathrm{~km}
$$$$
3 \cdot 3.1 \mathrm{~m}
$$$$
\text { Io- } 13 \mathrm{~km}
$$

none
Herbarium Material

$39-5$ I $\times 2$ I-30!11

6-10 $\mu \mathrm{m}$

3-4 $\mu \mathrm{m}$

4-9 $\mu \mathrm{m}$

$2 \mathrm{I} \mu \mathrm{m}$

There is, of course, no assurance that the endobiotic resting spores belong to the chytrid. However, in position (endobiotic) structure and size, they closely correspond to those found by de Bary (1884) which germinated to form an operculate epibiotic sporangium.

There is material in existence, therefore, which shows Braun's Chytridium olla to be essentially as he described it, i.e., with an epibiotic single, non-apophysate sporangium and broad tubular unbranched haustorial structure which undoubtedly branches within the ooplasm of the host. The sporangium bears a single operculum and the zoospores are formed endogenously. The resting spores are formed within the host. The Strasbourg material can be with confidence designated the type.

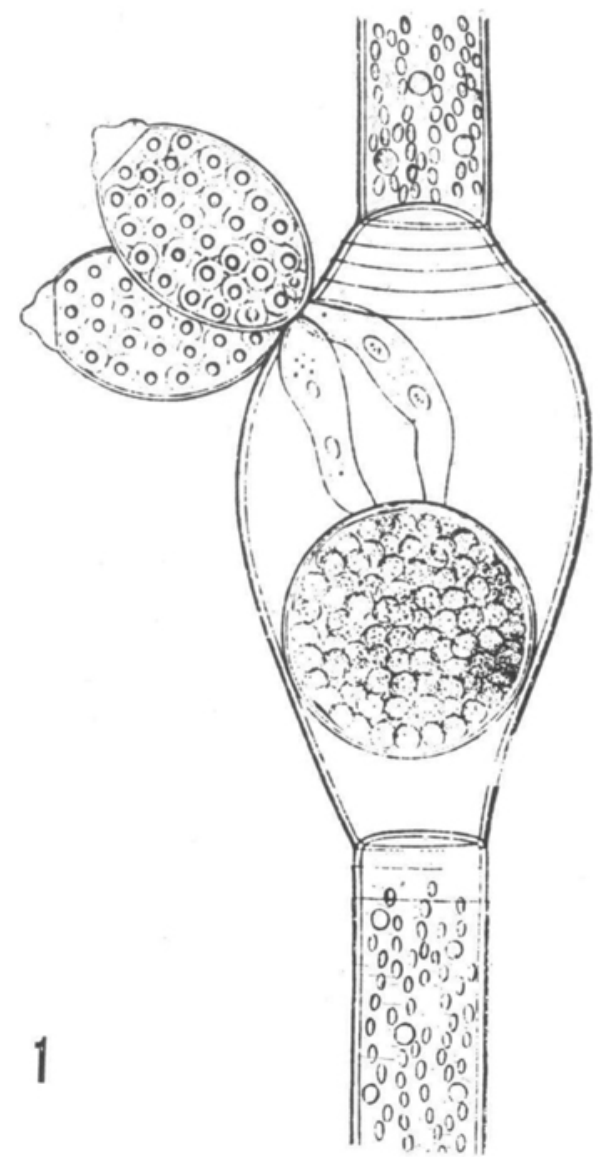

Fig. I. Oogonium of Oedogonium with two plants of Chytridium olla (mature sporangia) parasitic on the egg. The epibiotic operculate nature of the sporangium, endogenously formed zoospores and broad haustorial tube penetrating egg are clearly shown. (From Braun, 1856 ). 

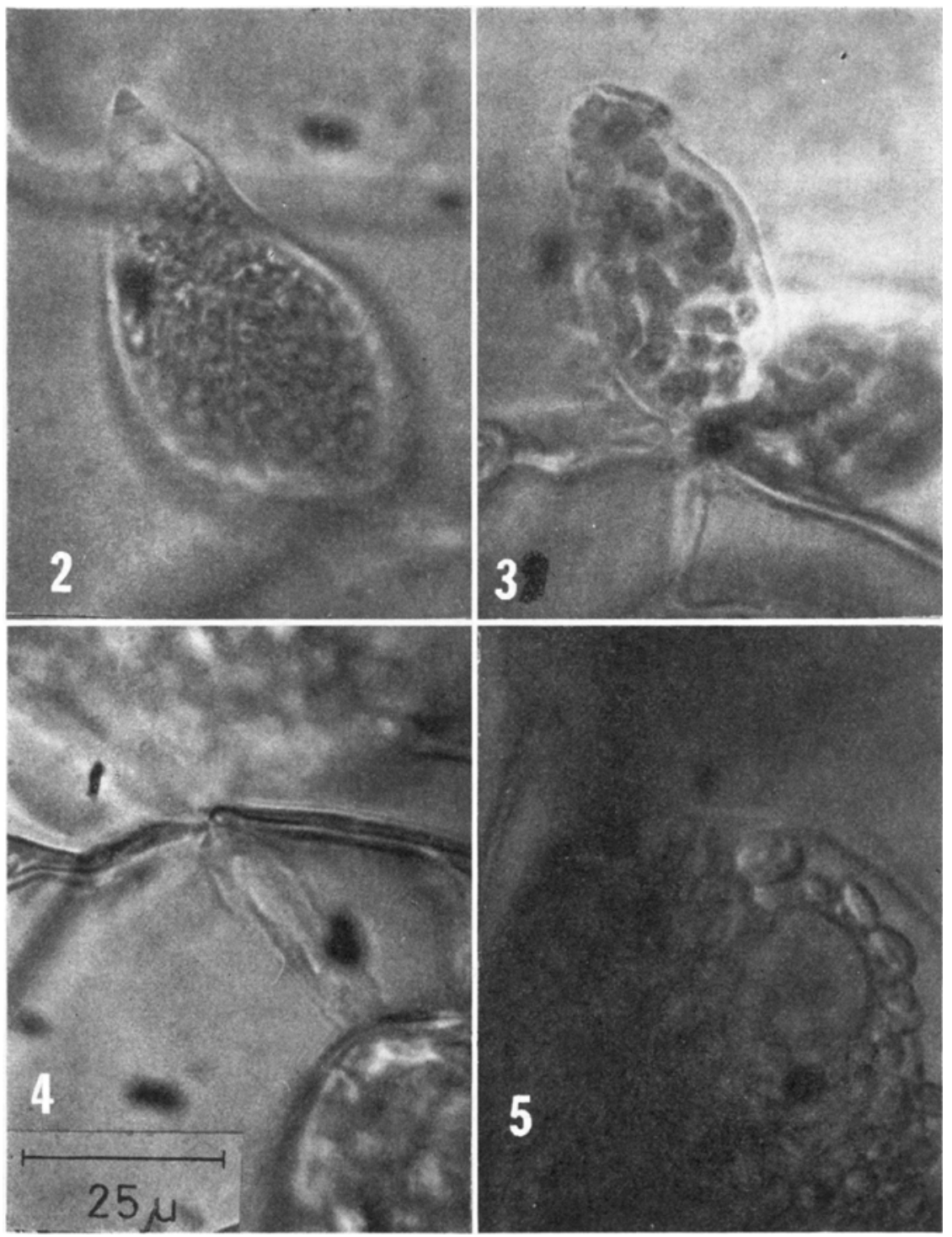

Fig. 2-5. Herbarium material of Braun's fungus after treatment with lacto-phenol. Fig. 2. Sporangium showing apical operculum. Fig. 3. Operculate sporangium showing endogenously formed zoospores and broad haustorial tube. Fig. 4. Base of large, empty sporangium showing broad haustorial tube and just within the host egg, to right, branching of tube. Fig. 5. Single endobiotic thick-walled resting spore in ooplasm of Oedogonium. All same magnification. (Pictures by Gunther Bahnweg).

\section{References}

BARY, A. DE 1884 - Vergleichende Morphologie und Biologie der Pilze, Mycetozoen und Bacterien, xvi + 558 pp. Leipzig.

Braun, A. 185I- Betrachtungen über die Erscheinung der Verjüngung in der Natur, ins- 
besondere in der Lebens- und Bildungsgeschichte der Pflanze. 363 pp. Leipzig.

BRAUN, A. I855-Ueber Chytridium, eine Gattung einzelliger Schmarotzergewächse auf Algen und Infusorien. Monatsber. Berlin. Akad. i 855 : 378-384.

BrAUN, A. I 856 - Ueber Chytridium, eine Gattung einzelliger Schmarotzergewächse auf Algen und Infusorien. Abhandl. Berlin. Akad. I 855:2 $1-83$.

Sparrow, F. K. 1958 - Interrelationships and phylogeny of the aquatic Phycomycetes. Mycologia 50: 797-8 I 3 .

\section{WORLD POLLENAAND SPORE FLORA (WPSF)}

At the first International Conference on Palynology held in Tuczon, USA, in 1962, Professor Gunnar Erdtman described his plans to publish a series of pollen and spore monographs in collaboration with taxonomists all over the world. In 1970 these plans were realized by the initiation of the World Pollen Flora edited by Gunnar Erdtman. Monographs on four families have been published. The desirability and need of having comprehensive palynological descriptions of plant families, or taxa of lower rank have since then been further discussed and confirmed. The Collegium Palynologicum Scandinavicum was keen to continue the World Pollen Flora project and ensure regular publishing and distribution. As a result of discussions during the 3 rd International Conference on Palynology in Novosibirsk, USSR, in 1971 , and correspondence with botanists throughout the world, agreement was eventually reached in the initiation of the World Pollen and Spore Flora (WPSF) under the auspices of Collegium Palynologicum Scandinavicum. World Pollen and Spore Flora consists of issues containing descriptions of pollen and spores of different families of spermatophytes, pteridophytes, bryophytes, and fungi. Larger families may be subdivided into suitable smaller taxonomic units. WPSF is distributed together with the journal Grana, by the Almquist \& Wiksell Periodical Company. An international Advisory Board Committee consisting of 21 members, has been appointed. Editorial policy, manuscript organization etc. appear in the Instructions for Authors included in each issue of WPSF. The first two issues treat the families Fouquieriaceae and Menyanthaceae.

It certainly involves great responsibility to be in charge of a long-term standard work like WPSF. The character and extent of the research materials, collections and traditions in the Palynological Laboratory provide, however, favorable support for the continuation and amplification of the World Pollen Flora concept introduced by the late Professor Gunnar Erdtman. The future progress of the WPSF depends to a great deal upon substantial contributions, including larger and more troublesome families or groups of general importance.

It is my sincere hope that the World Pollen and Spore Flora will aid scientists in various areas of research such as plant taxonomy, palaeobotany, geology, aeropalynology, ecology, and melitopalynology. 